\title{
Preserving the "Traditional Mosque" in the Modern World (A Conce Study of the Mosque in Islamic Architecture
}

mohamed alomar

\begin{abstract}
This study seeks to contribute to the clarification understanding the concept of the traditional Mosque through an exploration of historical and theoretical developments in traditional mosque architecture, especially with respect to The Muslim's relationship with the Divine, It traces the way in which Islamic Religious Architecture is an expression of the Muslim way of life, a product of religious requirements, and the result of unique cultural and environmental factors. It emphasizes how Mosque architecture is a sacred architecture that reflects the ideals of unification and solidarity within Muslim society.

It traces the way in which Islamic architecture was initiated by the Prophet Mohammed \{Peace be upon Him\}, when he built his mosque in Yathrib (al-Madmah), fourteen centuries ago, and how it rapidly became an extremely dynamic center for the new Muslim community, a place for the five daily congregational prayers and a model for Islamic communities of the future. This was a social environment, already folly regulated by Islamic law, "al-Shari'ah," derived from the Holy Qiira 'an and "Sunnah" (the customs) of the Prophet Mohammed \{Peace be upon Him\}, even though Islamic Law as a codified system would not be formalized for several hundred years to come.

It pays close attention to the concept of religious or sacred space, especially insofar as it is relevant to the Islamic Tradition and the way in which sacred architecture reflects a society's awareness of its relationship with the Divine. Through a comparison with Judaism and Christianity, Islam's sister Western religious traditions, especially the latter, It explores the various understandings of religious art and symbolism, as well as the unique historical realities that have shaped Muslim religious communities, and, subsequently, traditional mosque architecture. It also explores the diversity that is found in the architectural design of mosques and the key roles that mosques play in the definition of Islamic architecture in general.
\end{abstract}

